Britain's coast, although the extent of that fishing was not very great and Britain would need to consider with them what their position should be. It was hoped that the new arrangements could be brought into full operation by September.

The kernel of the Bill was in Clause 1, which provided for the extension of Britain's limits and for her control of access by foreign fishermen to the fisheries within these limits. The Convention provided that to qualify for recognition to be ablo to continue fishing between six and twelve miles this foreign fishing must have been carried on habitually during the ten years up to and including 1962 and that it must not be directed in future towards new grounds or new stocks of fish. In drawing up the designation orders, Mr. Soames said that Britain would, of course, need to take account of the fact that fish move round and that many species are often found on the same ground, but we would be able to distinguish betwoon herring fisheries, fisheries for white fish and shell fisheries. The power of designation was not limited to the vessels of countries which were party to the convention, and Britain's fishery agreement with Norway provided that if Britain established a fishery zone she would be prepared to make for Norwegian vessels arrangements corresponding to those which that agreement made for British vessels off Norway. The new base-lines which Britain was drawing were in conformity with the 1958 Geneva Convention and she would be able to close bays with straight lines up to 24 miles in length, whereas at present 10 miles are the maximum lengths for a bay closing line. Until the Bill came into full operation there would be a transitional period for traditional foreign fishing between three and six miles from base lines. This was dealt with in Clause 2.

The right to enforce conservation measures on British and foreign vessels was one to which Britain attached great importance, but it did not require new powers from the House. It was simply a question of adapting the powers which existed under present legislation to apply conservation regulations to British vessels. This was done in the first schedule to the Bill. Mr. Soames emphasized that Britain now had a modern instrument for promoting conservation through international cooperation in the North-East Atlantic Fisheries Commission of which all countries fishing in the north-east Atlantic without exception were members. It was the responsibility of this Commission to take all the measures that conservation demanded. At a meeting of the Commission in June on the initiative of Britain a special committee was set up which would be concerned with making collective arrangements for enforcing conservation measures on the high seas. This Committee would apply conservation measures to foreign vessels when they were fishing within Britain's own fishery limits as well as to British vessels. Mr. M. Noble expressed the hope that members of the North East Atlantic Fisheries Commission, which included Poland and other countries not signatories to the Convention, would be able to work together so that, while Britain could enforce within her twelve-mile limit the conservation measures which she thought right, these other countries would at the same time be able to work out conservation measures and internationally the same measures could be adopted and brought into force.

\title{
NUCLEAR POWER IN BRITAIN
}

$\mathrm{N}$ the debate in the House of Lords on June 10 on the White Paper, The Second Nuclear Power Programme (Nature, 202, 1247; 1964), Lord Coleraine was concerned with the reasons for Britain losing her commanding lead in this field to the United States, which he attributed to the organization of the nuclear power programme. This he thought was far less efficiently organized in Britain than in tho United States and this was partly because each power station carried an enormous load of research and development charges. $\mathrm{He}$ was concerned that the ordering of an American reactor system would mean that American technology would dominate the nuclear industry in Britain and that in effect she was opting out of that industry. He urged that the Government should take a hard look at the organization of the nuclear programme and particularly at the position of the Central Electricity Generating Board. He thought it was the function of that Board to provide the consumer in Britain with adequate supplies of cheap electricity, but that this function could not conceivably be combined with pioneering a new, expensive and complex industry. He did not think that a healthy nucloar industry could survive simply on the basis of copying designs. He suggested that the Atomic Energy Authority should be responsible for development until the first commercial station was in operation and proved, and then sell it to the Central Electricity Generating Board at a price which would meet the subsidy requested by the chairman of that Board. This was the systom adopted in Canada.

Lord Champion agreed that Britain did not have all the information which should be available when considering a matter of this immensity and importance. Moreover, she had not yet resolved the problem of the extent to which the Board and the Authority should bear the responsibility for research and development of civilian types of reactors and the legislation required to amend the A.uthority's statute. Nevertheless, he thought that The Second Nuclear Power Programme was right in its flexibility, but Viscount Caldecote thought that it was doubtful whether technical resources had been as well used as they could have been and that the responsibilities had not always been shared in the best way among industry, the Atomic Energy Authority and the Central Electrieity Generating Board. He thought it essential to see that scarce national technical resources were utilized to the best advantage, electrical power supplied as economically as possible, that there was an active research and development programme and that an efficient industry should be allowed to make reasonablo profits on the capital involved. The proper use of national resources, he pointed out, required a stable policy and that there should be no duplication between industry, the Authority and the Generating Board as well as a much better delineation of responsibility. A suitable administrative set-up in the Government was required to control the Generating Board, the Authority and research and development and production work as well as the share done in industry. Viscount Caldecote suggested that the research functions of the /Authority should be left under the Ministry for Science and Education and the responsibility of the Authority for development and collaboration with industry in their field reviewed. $\mathrm{He}$ entirely agreed with Lord Champion that Britain could not reject a system which was clearly and obviously more economic because it had been designed in the United States and not in Britain, but it was all too clear that it was very easy to have too much competition in these difficult technological and rapidly advancing fields.

Lord Stonham reiterated that not sufficient information was gonorally available for a proper judgment and that Britain should not reject an American system purely on the grounds that it was American. Lord Wolverton roferred to the higher efficiency of the new station at Bradwell in Essex which had a thermal efficiency of 26.5 
per cent compared with 19 per cent at Berkeley, Gloucestorshire. He thought much more basic research was required before Britain embarked on a larger programme than that announced by the Government.

Replying for the Government, Lord Derwent pointed out that the magnox system might still show advantages in some other countries and that Britain should not take too insular a view of these developments. The building and commissioning of the present stations had involved a great partnership between the Authority and the
Generating Board as well as with the Consortia, the contracting firms and the inspectorate of nuclear installations. The Government was satisfied that there was effective collaboration between the Generating Board and the Atomic Energy Authority, and there was, and always had been, close organization between the Consortia and the various firms in the contracting industry and these bodies. He agreed that the suggestion for adoption of systems and arrangements similar to that used in Canada merited careful consideration.

\title{
THE MUSEUMS ASSOCIATION
}

$\mathrm{T}$ THE seventieth annual conference of the Museums Association was held in Nottingham during July 13-17 under the presidency of Dr. D. John, director of the National Museum of Wales at Cardiff.

The proceedings opened in the spacious Great Hall in the Trent Building of the University with a welcome from the Lord Mayor of Nottingham. Dr. John in his presidential address outlined the financial difficulties which beset the Association and mentioned some of the proposed measures to be taken to remedy this state of affairs. $\mathrm{He}$ congratulated the Area Museum Councils on the work they had achieved in the early stages of their plan to regionalize museums. He also referred to the 1963 report of the Standing Commission and to the recommendations, some of which had not been implemented by H.M. Government. In conclusion, he considered that at the present time there was a greater consciousness concerning museums among the general public and that much is moving forward in the musoum world.

The general theme of the conference was that of "Public Relations" and this was introduced by Mr. C. Mann (president of the Institute of Public Relations), who gave a stimulating address on the importance of the public. $\mathrm{He}$ considered that the value of a work of art is in proportion to the number of people who see it, and for this roason museums should make every ondeavour to attract the public to their galleries. A genuine belief that the public really matters was a curatorial necessity and he urged his audience to make more use of exciting ontrance features, friendly and helpful attendants, and the creation of an atmosphere of goodwill.

Mr. C. Gibbs-Smith of the Victoria and Albert Museum followed with a paper on "The Fault . . . is . . . in Ourselves". He stated that good public relations meant plain good manners from the whole of the staff. He also felt that public relations should be the special duty of one member of staff who would be directly responsible to the director.

The theme was continued by Sir Frank Francis, director, British Museum, who said that museums though not in competition with themselves were certainly striving to gain customers in these days of more leisure and many interests. The aim of the curator should be to stimulate members of the public at all levels.

Mr. P. Johnstone (producer, B.B.C. Television) stressed the need for close co-operation between museums and the British Broadcasting Corporation. Both used visible communication methods and mutual help was essential. $\mathrm{He}$ advocated the setting apart of a special gallery in the museum for television work. Mr. I. Finlay, director of the Royal Scottish Museum, pertinently asked for what image was the museum striving and what public did we serve. A paper by the Rev. J. Jones-Davies describing the transformation of a small collection into a County Museum at Brecon closed the conference.

At the annual meeting, Mr. N. Cook, Guildhall Museum, London, was elected president for the year 1964-65 and an invitation to hold the annual meeting in Dublin in June 1965 was accepted with thanks.

Both the University and the City entertained the delegates at receptions, and during the meeting visits were arranged to the Newark and Derby Museums, Newstead Abbey, Boots Factory, Lincoln, Bakewell, Mansfield, Boston and other places.
F. S. WALLIS

\section{PENDULAR MOISTURE IN PACKINGS OF EQUAL SPHERES}

\author{
By Prof. COLIN C. HARRIS and Dr. NORMAN R. MORROW \\ Henry Krumb School of Mines, Columbia University, New York
}

\begin{abstract}
$\mathrm{E}^{\mathrm{x}}$ XPERIMENTAL relationships between capillary pressure, $P$, and saturation, $s_{w}$, often feature an 'irreducible' fluid content shown in Fig. I as the saturation $s_{w}^{*}$. In a random packing of equal spheres of radius $R$, the pendular rings found at the minimum saturation are not in equilibrium with each other and cover a distribution of sizes ${ }^{1}$. Values of $P R / \gamma$ calculated from the tables given by Fisher ${ }^{2}$ fall largely in the range 3-11 which is also the range of $P R / \gamma$ over which random packings of equal-sized hydrophilic spheres desaturate (Fig. 1, curve $R_{0}$ ), $\gamma$ being the air-water interfacial tension. Direct measurements of ring pressures by means of a micro capillary-probe showed that, for a given ring, the ring pressure is equal to the capillary pressure, $P$, at the time of formation, the error in moasurement being not more than 5 per cent $^{3}$. The ring pressure remains
\end{abstract}

constant once the ring has formed, provided that mass transfor to or from the ring is negligible ${ }^{3}$.

In the work recorded here, random packings of equalsized chrome steel spheres were saturated with dilute acid and thon the packing was drained in a fine-pored, frittedglass Buchnor filter to the irreducible saturation. A.fter about $0.5 \mathrm{~h}$, the spheres were cloarly etched over the areas of contact with tho retained fluid; this occurred as isolated or linked rings of fluid held around points of contact between the spheres. Circles, or for linkod rings equivalent circles, were selected at random and from thoir diameter, $L$ (inset in Fig. 1), the volume, $V$, and pressure deficiency of each ring were calculated ${ }^{2}$. The distribution of $L$ was found for three sphere sizes (diameter, $D=3 \cdot 18,4 \cdot 76,6 \cdot 35 \mathrm{~mm}$ ) taking two samples of 125 circles for each size of spheres. The cumulative 